\title{
Characteristics of the crustal and mantle structures across Lhasa terrane*
}

\author{
Hongwei Zheng ${ }^{1,2, \uparrow}$ Rizheng $\mathrm{He}^{2}$ and Xuan Guo ${ }^{3}$ \\ ${ }^{1}$ Department of Geophysics, Peking University, Beijing 100871, China \\ ${ }^{2}$ Institute of Geology, Chinese Academy of Geological Sciences, Beijing 100037, China \\ ${ }^{3}$ Research Institute of Petroleum Exploration and Development-Northwest (NWGI), \\ PetroChina, Lanzhou 730020, China
}

\begin{abstract}
Key words: the Dagze- Deqen-Duoma Profile; crust and mantle structure; Lhasa terrane
CLC number: P313 Document code: A
\end{abstract}

The Himalayan-Tibetan orogen is the youngest and arguably most spectacular of all the continent-continent collisional belts on the Earth. There are not only north-south extrusions but also east-west extensions in the Tibetan Plateau. All these phenomena are the results of the Indian plate subducting into the Eurasia plate about 70 Ma ago (Yin and Harrison, 2000), but the deep dynamics mechanism is still an enigma. Exploring the crust and upper mantle structure of Tibetan plateau and revealing the process and the effect of collision are crucial for solving the puzzle of the Tibet uplift and the continent-continent collision. This research is based on the data from the $360 \mathrm{~km}-$ long Dagze-Deqen-Domar profile, which can be divided into two sections. The Dagze-Deqen section traverses the Nyainqntanglha Mountains and the Yadong-Gulu rift, the biggest rift in the Tibet. The Deqen-Domar section crosses Lhasa terrane and Qiangtang terrane. We study the transverse density structure of the crust and mantle beneath the Dagze-Deqen-Domar profile using a joint gravity-seismic inversion technique in order to obtain the Moho and the asthenospheric configuration beneath the profile and understand the deep dynamics mechanism of the Yadong-Gulu rift.

\section{Regional geologic setting}

The Dagze-Deqen-Domar profile is located in the northern part of the Lhasa terrane and it traverses the following places from north to south in turn: Domar in the Qiangtang terrane, Za'gya Zangbo river, Baingoin in the Lhasa terrane and Bangong granite zone, Deqen, Nyainqntanglha Mountains, the Yadong-Gulu rift valley and Dagze.

The Bangong-Nujiang suture zone consists of a series of

\footnotetext{
* Received 16 March 2009; accepted in revised form 27 July 2009; published 10 August 2009.

• Corresponding author. e-mail: zhenghongwei004@sina.com
}

north-dipping or north-northeast dipping thrusts (Lü et al, 2003). The most intensively studied areas are the Nyainqntanglha shear zone and the NNE-striking Yadong-Gulu rift valley at the east side of the Nyainqntanglha shear zone. In the surface some strong strain tenacity happened with the normal fault characteristics in the rift areas. The rift footwall apparently rotated (Cogan et al, 1998). Armijo (1986) suggested that the rift has apparently shallow structure styles which are similar to the structure style glided along high-angle normal fault, and the amount of the east-west extension in the Lhasa terrane is about 2\%. Pan and Kidd (1992) identified Nyainqntanglha shear zone with normal-faulting, a SE-dipping shear zone with hundreds of meters thickened along the boundary of the middle of Nyainqntanglha Mountains (Ningzhong Valley).

\section{The crust-mantle density structure model of the Dagze-Deqen-Domar profile}

The mutual technique is a good tool for fitting gravity anomaly by polygon within space sections, which is a method of qualitative and half-quantitative analysis. Before modeling, it is required that we know a mass of important geological information, measured nature parameters in an area as a limitation, in order to design a reasonable geophysical model as a structure representation. In this way, we can acquire a pleasure model beneath the profile. In a word, the mutual technique of gravity anomaly modeling includes the following steps: (1) constructing a reasonable model according to multi-information from geological/geophysical/structure; (2) inputting some given initial parameter in the model; (3) computing theoretical gravity anomaly from the model; (4) comparison between the real anomaly and the theoretical value, to further modify the model; (5) computation until the difference between the real value and the theoretical value becomes little; (6) mapping the structure of the final model. 


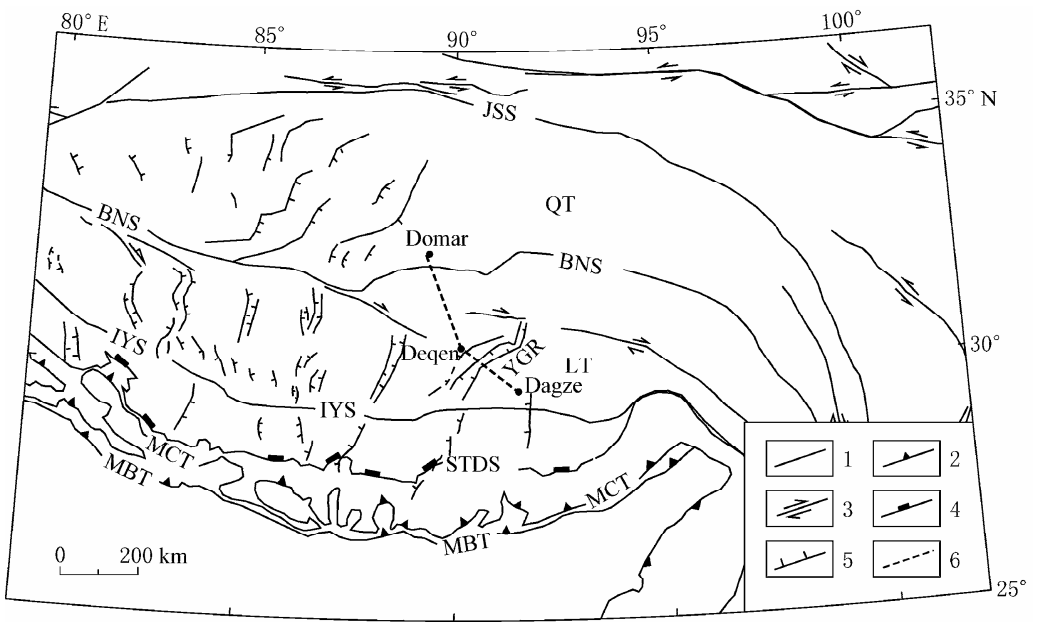

Figure 1 Location of the Domar-Deqen-Dagze profile. IYS: Indus-Yarlung Zangbo suture zone; BNS: Bangong-Nujiang suture zone; JSS: Jinshajiang suture zone; AKMS: A’Nyêmaqên-Kunlun-Muztag suture zone; MBT: Main boundary thrust; MCT: Main central thrust; STDS: South Tibet of detachment System; LT: Lhasa terrane; QT: Qiangtang terrane; YGR: Yadong-Gulu Rift. 1. Suture; 2. Thrust fault; 3. Strike-slip fault; 4. Normal fault; 5. Rift; 6. Profile.

\subsection{Model building and computation}

This study uses 1:1000 000 Bouguer gravity anomaly data.

The deep reflection seismic profile (Brown et al, 1996) along the Yadong-Gulu rift shows that there is a low velocity zone under the rift. The results of magnetotelluric sounding (Wei et al, 1997) and deep seismic sounding (Zhao et al, 2001) across the Nyainqntanglha Mountains display that there is a low-velocity and high-conductivity layer in the crust. A series of geophysics explorations (Kong et al, 1996; Wei et al, 1997) across the Bangong-Nujiang suture indicate that this suture is a north-dipping deep thrust. There exists a low-velocity (Zhang et al, 2001) and high-conductivity (Wei et al, 2001) melted body. According to velocity structure (Zhao et al, 2001) obtained from the deep seismic sounding of INDEPTH-III, we construct a crust and Moho structure model along Deqen-Domar profile. The Dagze-Deqen profile structures are obtained by using all deep exploration results mentioned above. After building initial models, we computed initial density for each body according to the Nafe-Drake formula relationship of primary wave velocity and density:

$$
\rho=\left\{\begin{array}{cc}
2.78+0.27\left(v_{\mathrm{P}}-6.0\right) & \left(v_{\mathrm{P}} \leq 7.0\right) \\
3.05+0.33\left(v_{\mathrm{P}}-7.0\right) & \left(7.0<v_{\mathrm{P}}<7.8\right), \\
3.05+0.33\left(v_{\mathrm{P}}-7.0\right)-0.1 & \left(v_{\mathrm{P}} \geq 7.8\right)
\end{array}\right.
$$

where $\rho$ is density, $v_{\mathrm{P}}$ is velocity of primary wave.

In the inversion, the lithospheric mantle and asthenosphere are assumed to be uniform. We extend the length of profile in order to diminish boundary effects.

\subsection{Characteristics of crust-mantle density structure}

The joint gravity-seismic inversion result is shown in Figure 2. The upper crust density is commonly less than $2.75 \times 10^{3} \mathrm{~kg} / \mathrm{m}^{3}$, the middle crust density varies between $2.80 \times 10^{3}$ and $2.85 \times 10^{3}$ $\mathrm{kg} / \mathrm{m}^{3}$, and the average lower crust density is $2.91 \times 10^{3}-3.01 \times 10^{3}$ $\mathrm{kg} / \mathrm{m}^{3}$. There is a big rupture beneath the Za'gyaZangbo river with uncertain depth. Beneath the Bangong belts of granite, there exists a north-dipping deeper fault, which disappears at the top of the Moho. At the southern side of the fault there is a low density zone of $2.58 \times 10^{3}-2.59 \times 10^{3} \mathrm{~kg} / \mathrm{m}^{3}$ in the depth of $30-40 \mathrm{~km}$. According to the research on helium isotope composition of hot spring's gas and geochemical characteristics of spring water ( $\mathrm{Li}$ et al, 2005), the low density layer was composed of silicate magma from the subducted Indian crust (Hou et al, 2006). There are two deep normal faults on the two sides of the Nyainqntanglha Mountains. They incise the low density zone in the middle crust beneath the Nyainqntanglha Mountains and the low density zone rises for about $8 \mathrm{~km}$. The crust structure beneath the Nyainqntanglha Mountains is similar to a horst. The thickness of the low density zone is more than $10 \mathrm{~km}$ in the east of the Nyainqntanglha Mountains, $10 \mathrm{~km}$ under the Nyainqntanglha Mountains and less than $10 \mathrm{~km}$ in the west of the Nyainqntanglha Mountains. The Yadong-Gulu rift is an inverse triangle low density body in the east of the horst. Its density is $2.53 \times 10^{3} \mathrm{~kg} / \mathrm{m}^{3}$ and its depth extends to $5 \mathrm{~km}$.

The lithospheric mantle is thin beneath the Nyainqntanglha Mountains on the profile, with an average depth of $75 \mathrm{~km}$, and gradually thickens on the two sides. The depth is $77 \mathrm{~km}$ on the south side and $73 \mathrm{~km}$ on the north side. The average density of the lithospheric mantle is $3.33 \times 10^{3} \mathrm{~kg} / \mathrm{m}^{3}$. In the inversion, the asthenosphere was taken into consideration for modeling. The initial asthenospheric top boundary followed the results of the Rayleigh wave dispersion (Zhang et al, 2007). Its density is $3.22 \times 10^{3} \mathrm{~kg} / \mathrm{m}^{3}$ and its top boundary protrudes upward, like an anisomerous anticline. The bottom depth of the asthenospheric mantle is divided by the Nyainqntanglha Mountains, which sharply increases from $110 \mathrm{~km}$ to $137 \mathrm{~km}$ southward and slowly climbs from $110 \mathrm{~km}$ to $120 \mathrm{~km}$. 

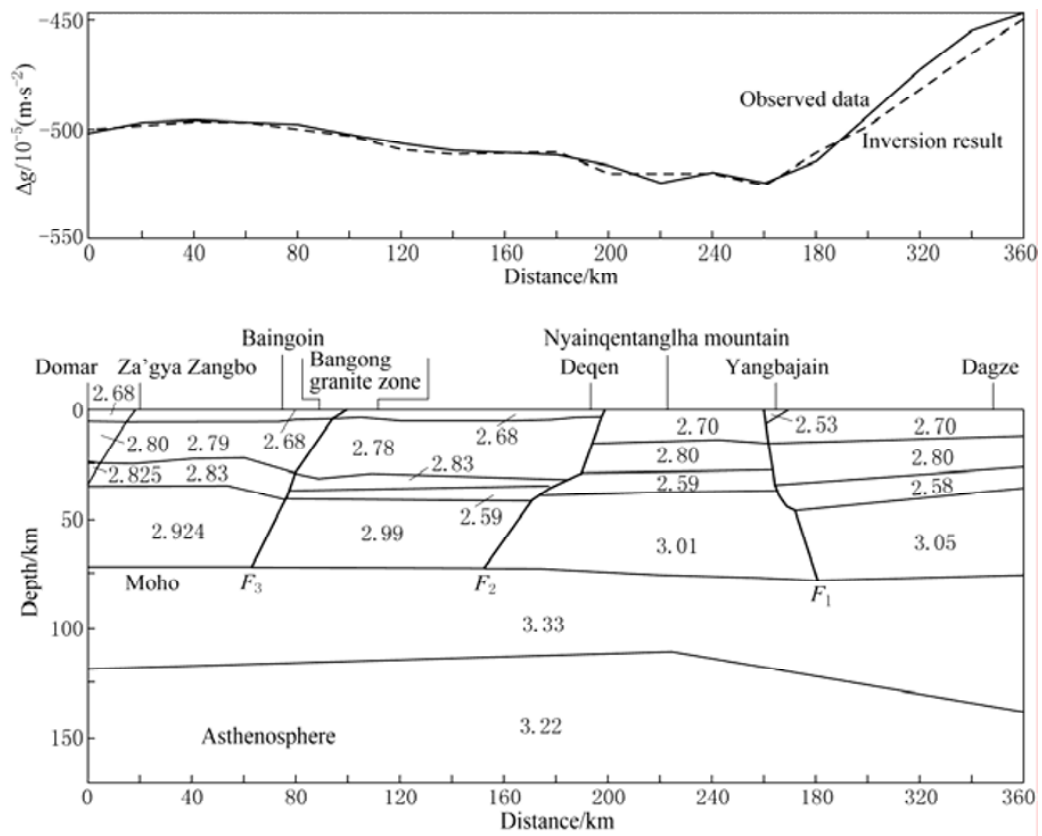

Figure 2 The crust-mantle density structure model of the Dagze-Deqen-Domar profile.

\section{Discussion and conclusions}

Two-dimensional crust-mantle density structure of the Dagze-Deqen-Domar profile computed by joint gravity-seismic inversion technique indicates that the low velocity zone in the mid-crust of Lhasa terrane is cut by Nyainqntanglha horst. The Moho surface is deep in the east of the Nyainqntanglha Mountains, and shallow in the west. The top boundary of the asthenosphere protrudes upward, like an anisomerous anticline. The smallest depth of the asthenosphere is $110 \mathrm{~km}$ and it increases rapidly southward and slowly northward.

The research results show that the rigid Indian lithosphere, the weak lower crust and anisotropic mantle of Tibet make it possible that the Indian lithospheric mantle subducted far away from south to north and the Tibet mantle detached from the crust. Receiver function images (Kosarev et al, 1999) indicate that the Indian lithospheric crust breaks off from mantle and its lithospheric mantle northward subducted northward into the Qiangtang terrane (Owens and Zandt, 1997). Tomographic imaging (Zheng et al, 2007) shows that the Indian lithospheric mantle subducting angles are different in different areas, but their front locations are all beneath the Qiangtang terrane. Potassic lavas eruption time is early in the south and late in the north. It shows that Indian lithospheric mantle subducted from south to north and has reached the Qiangtang terrane (Chung et al, 2005). The profile density image reveals that the bottom boundary of the lithospheric mantle is obviously protrudes upward, like an anisomerous anticline (Larson et al, 1999). Yadong-Gulu rift east of this anticline may be caused by the deep mantle eastward escape (Tapponnier et al, 1982) and Nyainqntanglha active ductile shear (Harrison et al, 1995).

This paper is an experiment of depicting the lithospheric density structure in Tibet. In the future, more and more geophysical explorations will help us understand the crustal and mantle structure of the Tibetan Plateau lithosphere.

Acknowledgements This work was supported by National Natural Science Foundation of China (Nos.40404011 and 40774051), National Probing Project (SinoProbe-02) and the Basic outlay of scientific research work from the Ministry of Science and Technology of the People's Republic of China in 2007, 2008, 2009.

\section{References}

Armijo R, Tapponnier P,Mercier J L and Han T L (1986). Quaternary extension in southern Tibet: Field observations and tectonic implication. J Geophys Res 91: 13 803-13 872.

Brown L D, Zhao W J, Nelson K D, Hauck M, Alsdorf D, Ross A, Cogan M, Clark M, Liu X W and Che J K (1996). Bright spots, structure, and magmatism in Southern Tibet from INDEPTH seismic reflection profiling. Science 274(6): 1688-1690.

Chung S L, Chu M F, Zhang Y Q, Xie Y W, Lo C H, Lee T Y, Lan C Y, Li X H, Zhang Q and Wang Y Z (2005). Tibetan tectonic evolution inferred from spatial and temporal variations in post-collisional magmatism. Earth Science Reviews 68: 173-196.

Cogan M J, Nelson K D, Kidd W S F and Wu C (1998). Shallow structure of the Yadong-Gulu rift, Southern Tibet, from refraction analysis of Project INDEPTH. Tectonics 17(1): 46-61.

Harrison T M, Copeland P, Kidd W S F and Lovera O (1995). Activation of the Nyainqentanghla shear zone: Implication for uplift of the southern Tibetan Plateau. Tectonics 14: 658-676.

Hou Z Q, Zhao Z D, Gao Y F, Yang Z M and Jiang W (2006). Tearing and dischronal subduction of the Indian continental slab: Evidence from $\mathrm{Ce}$ nozoic Gangdese volcano-magmatic rocks in south Tibet. Acta Petrologica Sinica 22(4): 761-774.

Kong X R, Wang Q S and Xiong S B (1996). The research of the west of Tibet plateau synthesis geophysics and Lithosphere structure. Science in China (Series D) 26(4): 308-315 (in Chinese with English abstract). 
Kosarev G, Kind R, Sobolev S V, Yuan X, Hanka W and Oreshin S (1999). Seismic evidence for a detached Indian lithospheric mantle beneath Tibet. Science 283: 1306-1 309.

Li Z Q, Hou Z Q, Nie F J, Yang Z S, Qu X M, Meng X J and Zhao Y Y (2005). Characteristic and distribution of the partial melting layers in the upper crust: evidence from active hydrothermal fluid in the South Tibet. Acta Geologica Sinica 79(1): 68-77 (in Chinese with English abstract).

Larson K, Burgmann R, Bilham R and Freymueller J (1999). Kinematics of the India-Eurasia collision zone from GPS measurements. J Geophys Res 104: $1077-1093$.

Lü P, Qu Y G, Li Q W and Wang H S (2003). Shelincuo and Bangecuo extensional lake basins in the northern part of Tibet and present chasmic activities. Jilin Geology 22(2): 15-19 (in Chinese).

Owens T J and Zandt G (1997). Implications of crustal property variations for models of Tibetan plateau evolution. Nature 387: 37-43.

Yin A and Harrison T M (2000). Geologic Evolution of the Himalayan-Tibetan orogen. J Ann Rev Earth Planet Sci 28: 211-280.

Pan Y and Kidd W S F (1992). Nyainqentanghla shear zone: A late Miocene extensional detachment in the southern Tibetan Plateau. Geology 20: 775-778.

Tapponnier P, Molnar P and Armijo R (1982). Propagation extrusion tectonics in Asia: New insights from simple experiments with plasticine. Geology 10: 611-616.

Wei W B, Chen L S, Tan H D, Hu J D, Deng M and Jin S (1997). Features of thermal structure and highly conductive bodies in middle crust beneath centraland southern Tibent according to INDEPTH MT results. Geoscience 11(3): 365-374 (in Chinese with English abstract ).

Wei W B, Unsworth M, Jones A, Booker J, Tan H D, Nelson D, Chen L S, Li S H, Solon K, Bedrosian P, Jin S, Deng M, Ledo J, Kay D and Roberts B (2001). Detection of widespread fluids in the Tibetan crust by magnetotelluric studies. Science 292: 716-718.

Zhang X M, Sun R M and Teng J W (2007). Study on crustal, lithospheric and asthenospheric thickness beneath the Qinghai-Tibet Plateau and its adjacent areas. Chinese Science Bulletin 52(6): 797-804 (in Chinese with English abstract).

Zhang Z J, Li Y K, Wang G J, Teng J W, Klemplerer S, Li J W, Fan J Y and Chen Y (2001). East-western striking crustal structure beneath the North Tibet and concave Moho-from the reveal of wide-angle reflection profile. Science in China (Series D) 31(11): 881-888 (in Chinese with English abstract).

Zhao W J, Mechie L, Brown D, Guo J, Haines S, Hearn T, Klemperer S L, Ma Y S, Meissner R, Nelson K D, Ni J F, Pananont P, Rapine R, Ross A and Saul J (2001). Crustal structure of central Tibet as derived from project INDEPTH wide-angle seismic data. Geo J Int 45(3): 486-498.

Zheng H W, Li T D, Gao R, Zhao D P and He R Z (2007). Teleseismic P-wave tomography evidence for the Indian lithospheric subducting northward beneath the Qiagntang terrane. Chinese J Geophys 50(5): 1418-1 426 (in Chinese with English abstract). 